\title{
Changes in Nursing Work and Repercussions for Worker Health
}

\author{
Macedo ABT*, Antoniolli L, Urrea Vega EA and Cocaro de Souza SB \\ Clinical Hospital of Porto Alegre, Brazil
}

*Corresponding author: Andreia Barcellos Teixeira Macedo, Clinical Hospital of Porto Alegre, Porto Alegre, Rio Grande do Sul, Brazil, Email: amacedo@hcpa.edu.br

\section{Mini Review \\ Volume 4 Issue 4}

Received Date: October 12, 2020

Published Date: November 02, 2020

DOI: $10.23880 /$ nhij-16000228

\section{Abstract}

Work is configured as one of the determinants of the health situation of individuals. At the same time that it contributes to the construction of subjectivity, producing meaning for the existence and meaning of life, it can trigger the illness of the worker. Health care, as well as the organization of nursing work, has been changing over the years, generating several occupational risks, which can have serious consequences for the physical and mental health of the worker. This study is a small review of changes in the world of nursing work, from the period of modern nursing to the present, considering factors such as the Fourth Industrial Revolution and the pandemic of COVID 19. Emphasizes and reflects on the increase of involvement on psychosocial risks. Our intention with this brief article is to provoke professionals to think about a new way of working seeking health for the nursing team. Maintaining healthy environments in places where we work with the pain of others is not an easy task. We need to create a habit of taking care and strengthening ourselves, to assist others with quality.

Keywords: Nursing; Occupational Health; Occupational Diseases

Work is configured as one of the determinants of the health situation of individuals. At the same time that it contributes to the construction of subjectivity, producing meaning for the existence and meaning of life, it can trigger the illness of the worker. Health care, as well as the organization of nursing work, has been changing over the years, generating several occupational risks, which can have serious consequences for the physical and mental health of the worker $[1,2]$.

In the 19th century, modern nursing was born with the influence of the Taylorist and Fordist models and the biomedical and positivist paradigms, with hierarchical, technicist subdivisions, prevailing rationality and disregarding the individuality of the subjects who received assistance and that of the workers themselves. The health of the nursing worker was a subject with no scientific and legal dimension. Later, Toyotism presented ways of organizing work based on the diversification of operations and the involvement of workers with the company's objectives. For nursing, it was the beginning of using technology, taking care of the machine in addition to taking care of the patient, and producing more [3].

Intense work with a tense flow is increasingly common in health institutions, mixing characteristics of Toyotism and Taylorism. The imposition of goals, the extension of the workday and the requirement for the worker's versatility are aspects of the intensity that precarious the relations and working conditions, from this period [4]. This acceleration in the pace of work and increased physical effort brought musculoskeletal diseases, identified in the 90 s as the biggest occupational health problem for nursing. Musculoskeletal pain in nursing professionals has been extensively investigated worldwide, occurring with greater prevalence in nursing technicians and assistants and affecting mainly the lumbar region, followed by shoulders and neck [5].

Currently, the period known as the Fourth Industrial Revolution, the work is characterized by the use of multiple technologies that eliminate the barriers between physical and digital, cloud computing, biotechnology, robotics, among 
others, that connect people in real time. Globalization has enabled the insertion of new technologies, changing the way of caring, with the generation of multitasking professionals, always connected with work [6]. In nursing, the changes have been demanding a super specialization of the professional. Another aggravating factor of this period are the quality management and safety care programs, which tend to produce greater demand for work, generating occupational overload and increasing psychosocial risks [7]. Under a new logic, health institutions started to be managed as companies, within the perspective of capitalism. The professionals' concern ceased to be merely care at the bedside, and began to focus on productivity, goals, skills and quality indicators.

More recently, nursing started to act on the front line of COVID 19. It was a sudden change in the way of working, adding to the fear of the unknown, the lack of protective equipment, the difficulty in building protocols and providing the team with training in such a short time, as well as care for yourself and the colleague who falls ill. International organizations have publicly made clear the enormous contribution of nursing professionals at the forefront of the fight against COVID-19. In this scenario, psychosocial risks are identified as major contemporary threats to workers' health, as they are potential generators of suffering and disability, leading to a decrease or loss of quality of life, an increased risk of social exclusion and morbidity and mortality [8].

Among the psycho-emotional stress evidenced in the literature, compassion fatigue has been considered an important threat to the health of professionals who deal with lives. Compassion fatigue, considered a psychic, nonpsychotic disorder, develops when the health professional experiences excessive compassion and altruism when sharing patients' negative senses, associated with nonexistent or inappropriate strategies to face the feelings that emerge in a healthy way the stress and discomfort that other people's suffering can cause. As well as insufficient feeling of reward for their work [9].

In view of the multidimensionality of compassionate fatigue and negative reflexes to nursing professionals, it is essential to stimulate the positive aspects of the Quality of Professional Life (QLP), and to develop the ability to overcome adverse work situations. In this sense, professionals should be instrumentalized in the use of coping skills, with cognitive and behavioral efforts and skills consciously used by the worker to deal with the demands, external or internal, of their relationship with the work environment, in order to adapt in order to minimize the psycho-emotional suffering and illness caused by them [10].

Investing in stress reduction and occupational risk programs that are inherent to the profession are mandatory for maintaining worker health and consequent reduction in absenteeism, improving the capacity for individual and institutional resilience, given that resilience is influenced by factors risk, and individual, family and environmental protection / promotion factors, resulting in the individual's abilities and flexibility to recover psychic and mental health after experiencing difficult, challenging, crisis or suffering situations [11].

The world of work is changing and there is no way to stop technological advances and developments in health care. The modern work context requires that the worker is flexible and able to constantly adapt to the new demands and adversities, thus reducing the risk of illness due to occupational stress. Resilient professionals have adaptive responses to occupational stressors and hardly develop pathologies linked to exposure to occupational stress.

The strengthening of the individual reflects on the health of the team and the organization. The ability to deal with adversity can be developed, but for that it is necessary to engage the worker, the leaders involved and the organization. Promoting resilience means enabling individuals to face adversity and obtain more adjusted responses, with less risk of becoming ill, that is, promoting resilience makes it possible to promote health in the workplace.

Our intention with this brief article is to provoke professionals to think about a new way of working seeking health for the nursing team. Maintaining healthy environments in places where we work with the pain of others is not an easy task. We need to create a habit of taking care and strengthening ourselves, to assist others with quality.

\section{References}

1. Rohm RHD, Lopes NF, Rohm RHD, Lopes NF (2015) 0 novo sentido do trabalho para o sujeito pós-moderno: uma abordagem crítica. Cad Ebapebr 13(2): 332-345.

2. Rosado IVM, Russo GHA, Maia EMC (2015). Produzir saúde suscita adoecimento? As contradições do trabalho em hospitais públicos de urgência e emergência. Cien Saude Colet 20(10): 3021-3032.

3. Donoso MTV, Wiggers E (2020) Discorrendo sobre os períodos pré e pós Florence Nightingale: a enfermagem e sua historicidade. Enfermagem em Foco 11(1 Esp).

4. Santos, TA, Santos HS, Sampaio ES, Melo CMM, Souza EA, Pires CGS (2020) Intensity of nursing work in public hospitals. Rev Latino-Am Enfermagem 28.

5. Dutta, D, Bharati S, Roy C, Das G (2013) Measurement of 
prevalence of major depressive syndrome among Indian patients attending pain clinic with chronic pain using PHQ-9 scale. J Anaesthesiol Clin Pharmacol 29(1): 76-82.

6. Bessa MEP, De Almeida MI, Araújo MFM, Da Silva MJ (2010) Riscos ocupacionais do enfermeiro atuante na estratégia saúde da família. Revista Enfermagem 18(4): 644-649.

7. Cabeças J (2015) Taxonomy to characterize occupational hazards (risk factors) at the workplace level. Work 51(4): 703-713.

8. García del CJ (2012) Concepto de percepción de riesgo y su repercusión en las adicciones. Health \& Addictions / Salud Y Drogas 12(2): 133-151.

9. Quintana ZO, Paravic KM (2014) Quality of work life in nursing staff. Revista Brasileira De Enfermagem 67(2): 302-305.

10. Merlo ARC, Lapis NL (2007) A saúde e os processos de trabalho no capitalismo: reflexões na interface da psicodinâmica do trabalho e da sociologia do trabalho. Psicologia \& Sociedade 19(1): 61-68.

11. Angst R (2009) Psicologia e resiliência: uma revisão de literatura. Psicol. Argum 27(58): 253-260. 